\title{
ANALISIS PENGARUH MOTIVASI DAN DISIPLIN KERJA TERHADAP KINERJA MANAJER PROYEK KONSTRUKSI
}

\author{
Felix Julian ${ }^{1}$, Jane Sekarsari T. ${ }^{2}$ \\ ${ }^{1}$ Program Studi Sarjana Teknik Sipil, Universitas Tarumangara, Jl.Letjen S. Parman No.1 Jakarta \\ Email: felixjulian97@ hotmail.com \\ ${ }^{2}$ Program Studi Sarjana Teknik Sipil, Universitas Tarumangara, Jl.Letjen S. Parman No.1 Jakarta \\ Email: tamtana.js@gmail.com
}

\begin{abstract}
ABSTRAK
Keberhasilan suatu proyek konstruksi dipengaruhi oleh kinerja manajer proyek konstruksi tersebut. Salah satu cara mengukur kinerja manajer proyek konstruksi dapat melalui kinerja waktu proyek yang dikerjakannya. Penelitian-penelitian yang telah dilakukan sebelumnya menunjukkan bahwa motivasi dan disiplin kerja memiliki pengaruh signifikan terhadap kinerja seseorang. Oleh karena itu, studi ini ingin melakukan penelitian pengaruh motivasi dan disiplin kerja secara bersamaan terhadap kinerja manajer proyek konstruksi. Penelitian dilakukan dengan penyebaran kuesioner kepada sejumlah responden yang meliputi manajer proyek, manajer lapangan, manajer teknik, dan manajer-manajer lainnya. Teknik analisis data menggunakan bantuan program SPSS. Analisis data dilakukan mulai dari uji validitas dan uji reliabilitas, uji asumsi klasik (meliputi uji normalitas, linearitas, multikolinearitas, dan heteroskedastisitas), uji koefisien determinasi, uji t, dan uji F. Hasil dari analisis yang dilakukan menunjukkan bahwa motivasi dan disiplin kerja memberikan pengaruh sebesar 56,3\% terhadap kinerja manajer proyek konstruksi. Berdasarkan uji t dan uji $\mathrm{F}$, dapat diketahui bahwa motivasi dan disiplin kerja memiliki pengaruh yang signifikan secara individual maupun secara bersamaan terhadap kinerja manajer proyek konstruksi. Pada kelompok motivasi kerja, faktor yang paling berpengaruh adalah memiliki hubungan baik antar sesama rekan kerja dalam proyek dan dapat diajak bekerja sama. Sedangkan pada kelompok disiplin kerja, faktor yang paling berpengaruh adalah merasa bertanggung jawab terhadap pekerjaan yang dilakukan..
\end{abstract}

Kata kunci: motivasi kerja, disiplin kerja, kinerja manajer proyek konstruksi.

\section{PENDAHULUAN}

\section{Latar belakang}

Keberhasilan suatu proyek konstruksi dipengaruhi oleh kinerja manajer proyek konstruksi tersebut. Kinerja seseorang dapat dipengaruhi oleh beberapa faktor, salah satunya adalah faktor motivasi. Motivasi dapat menjadi pendorong seseorang dalam melaksanakan suatu kegiatan guna mendapatkan hasil yang terbaik. Dengan adanya motivasi, seseorang akan memiliki semangat yang tinggi dalam melaksanakan tugas yang dibebankan kepadanya.

Penelitian yang dilakukan Wang D., et al. (2017) menunjukkan faktor motivasi yang paling berpengaruh terhadap kinerja manajer proyek konstruksi di Amerika Serikat adalah meraih keberhasilan dalam pekerjaan, adanya partisipasi dalam pembuatan keputusan, dan memiliki rasa saling percaya dengan atasan. Sedangkan pada penelitian Aziz dan Benny (2017), faktor gaji yang cukup untuk memenuhi kebutuhan, adanya bonus atau upah tambahan, dan adanya pembayaran uang lembur merupakan faktor motivasi yang paling berpengaruh terhadap kinerja pekerja proyek konstruksi.

Faktor lainnya yang juga dapat memengaruhi kinerja adalah sikap disiplin dalam bekerja. Penelitian yang dilakukan oleh Narpaduhita (2016) menunjukkan disiplin memiliki pengaruh yang signifikan terhadap kinerja mandor. Hasil penelitian lainnya yang dilakukan Almutahar et al. (2015) dan Nadiah et al. (2012) menyimpulkan bahwa sikap disiplin kerja mampu meningkatkan produktivitas tenaga kerja.

Dengan melihat pentingnya peran manajer proyek konstruksi dan besarnya pengaruh motivasi dan disiplin kerja terhadap kinerja seseorang, maka studi ini ingin meneliti pengaruh motivasi dan disiplin kerja secara bersamaan terhadap kinerja manajer proyek konstruksi. Hal ini dapat berguna agar motivasi dan disiplin kerja juga diterapkan kepada manajer proyek konstruksi. 


\section{TINJAUAN PUSTAKA}

\section{Motivasi kerja}

Motivasi merupakan suatu perubahan pada diri seseorang yang muncul karena adanya gejala perasaan, kejiwaan, dan emosi sehingga mendorong individu untuk sesuatu yang disebabkan karena kebutuhan, keinginan, dan tujuan (Aziz dan Benny, 2017). Motivasi mengajarkan bagaimana caranya mendorong semangat kerja seseorang agar orang tersebut mau bekerja lebih giat dan bekerja keras dengan menggunakan seluruh kemampuan dan keterampilan yang dimilikinya. Oleh karena itu, sebuah perusahaan perlu memperhatikan kebutuhan pekerjanya.

Hal ini dapat dilakukan dengan berpatokan pada teori motivasi Maslow karena teori ini berfokus terhadap kebutuhan seseorang. Abraham Maslow mengemukakan bahwa pada dasarnya semua manusia memiliki kebutuhan pokok, dimana variasi kebutuhan manusia dipandang tersusun dalam bentuk hirarki dalam lima tingkatan yang berbentuk piramida dan orang memulai dorongan dari tingkat terbawah. Kelima kebutuhan menurut Maslow adalah sebagai berikut (Yusuf, 2018):

a. Kebutuhan Fisiologis (Physiological Needs)

Kebutuhan ini merupakan kebutuhan paling dasar dari kehidupan manusia. Kebutuhan ini dapat dicontohkan seperti kebutuhan akan makanan, tempat tinggal, pakaian, dan kebutuhan-kebutuhan dasar lainnya. Dalam aplikasinya, kebutuhan ini biasanya dipenuhi melalui gaji atau upah yang diberikan oleh perusahaan.

b. Kebutuhan Rasa Aman (Safety Needs)

Apabila kebutuhan fisiologis relatif sudah terpenuhi, maka muncul kebutuhan kedua yaitu kebutuhan akan rasa aman. Pemenuhan kebutuhan ini biasanya dilakukan oleh perusahaan dengan memberi asuransi kesehatan, asuransi jiwa, jamsostek, pensiun, dan lain-lain.

c. Kebutuhan Sosial (Social Needs)

Sebagai makhluk sosial, seorang individu tentunya ingin diterima oleh masyarakat dan lingkungannya. Dalam suatu perusahaan biasanya kebutuhan ini dapat terpenuhi melalui menjalin persahabatan dengan rekan sekerja atau satu tim, adanya interaksi antara atasan dan bawahan, dan hubungan atau komunikasi yang baik di dalam perusahaan.

d. Kebutuhan Pengakuan (Esteem Needs)

Kebutuhan ini dapat diperoleh melalui penghormatan dari orang lain, memiliki status atau popularitas yang lebih tinggi, mendapatkan pujian, dan mendapatkan penghargaan atas kontribusi yang telah diberikan. Pemenuhan kebutuhan ini dalam perusahaan dapat berupa promosi jabatan.

e. Kebutuhan Aktualisasi Diri (Self Actualization Needs)

Kebutuhan ini merupakan kebutuhan untuk menunjukkan potensi kemampuan yang berbeda dan lebih baik dari yang lain dalam menyelesaikan sesuatu. Pemberian kesempatan untuk menyelesaikan pekerjaan yang menantang dan kesempatan untuk bekreasi dan berinovasi merupakan cara-cara yang dapat ditempuh atau dilakukan oleh perusahaan untuk memenuhi kebutuhan ini.

\section{Disiplin kerja}

Disiplin kerja yaitu suatu sikap, tingkah laku, dan perbuatan yang sesuai dengan peraturan baik tertulis maupun tidak tertulis, dan bila melanggar akan ada sanksi atas pelanggarannya. Hal ini bertujuan untuk meningkatkan kesadaran dan kesediaan seseorang dalam menaati semua peraturan perusahaan dan norma-norma sosial yang berlaku (Widayaningtyas, 2016).. Hal ini dapat membuat suatu perusahaan atau organisasi meraih tujuannya (Narpaduhita, 2016).

Bentuk - bentuk disiplin kerja terdiri dari beberapa macam. Handoko (1990) seperti dikutip Nadiah et al. (2012) menyatakan bahwa disiplin mempunyai tiga macam bentuk, di antaranya:

a. Disiplin preventif adalah kegiatan yang dilaksanakan untuk mendorong karyawan agar mengikuti berbagai standar dan pertauran yang telah ditetapkan, sehingga pelanggaran atau penyelewengan dapat dicegah.

b. Disiplin korektif adalah tindakan yang diambil untuk menangani pelanggaran terhadap aturan-aturan dan mencoba untuk menghindari pelanggaran-pelanggaran lebih lanjut.

c. Disiplin progresif, yang berarti memberikan hukuman atau sanksi yang lebih berat terhadap pelanggaranpelanggaran yang berulang. Akhir dari sebuah disiplin progresif bisa berupa pemutusan hubungan kerja, karena memang kompetensi karyawan yang tidak sesuai atau memang karyawan tersebut menolak untuk melakukan perbaikan (improvement).

Sedangkan berdasarkan jenisnya, disiplin kerja dapat timbul dari diri sendiri dan dari perintah, yang terdiri dari:

a. Self imposed discipline yaitu disiplin yang timbul dari diri sendiri atas dasar kerelaan, kesadaran, dan bukan timbul atas dasar paksaan.

b. Command discipline yaitu disiplin yang timbul karena adanya paksaan, perintah, dan hukuman dari orang lain. 
Jenis disiplin yang diinginkan dalam setiap organisasi ataupun perusahaan adalah jenis disiplin yang timbul dari diri sendiri atas dasar kerelaan dan kesadaran. Akan tetapi dalam realitanya selalu menyatakan bahwa disiplin itu lebih banyak disebabkan karena adanya paksaan dari luar (Nadiah et al, 2012 dalam Handoko, 2008).

\section{Pengertian dan tugas manajer proyek konstruksi}

Manajer adalah seseorang yang menduduki posisi formal tertentu di dalam sebuah organisasi atau perusahaan, dan memiliki tanggung jawab terhadap sedikitnya pekerjaan satu orang (bawahannya) serta mempunyai wewenang atau otoritas formal atas orang tersebut. Menurut Yusuf (2018), tugas-tugas dari seorang manajer adalah sebagai berikut:

1. Memimpin organisasi/perusahaan

2. Mengendalikan dan mengatur organisasi/perusahaan

3. Membangun kepercayaan antar karyawan

4. Mengembangkan kualitas organisasi/perusahaan

5. Mengevaluasi aktivitas organisasi/perusahaan

6. Menjadi problem solver bagi permasalahan organisasi/perusahaan

Manajer proyek konstruksi meliputi manajer proyek, manajer lapangan (site manager), manajer teknik (engineering manager), dan manajer-manajer lainnya yang memiliki tugas atau tanggung jawabnya masing-masing. Seorang manajer proyek memiliki beberapa kewajiban seperti melakukan pengawasan agar proyek yang ditanganinya dapat selesai sesuai dengan waktu, mutu, dan biaya yang telah ditentukan, mengevaluasi kinerja subkontraktor, mengidentifikasi dan menyelesaikan potensi masalah yang akan timbul, serta merekrut, melakukan pelatihan, mengorganisasikan, berkoordinasi, dan memotivasi para pekerja untuk mencapai hasil yang telah ditentukan. Manajer lainnya yaitu manajer lapangan (site manager) yang merupakan penanggung jawab pada pekerjaan langsung di lapangan. Seorang site manager memiliki tugas untuk mengadakan kontrol terhadap pelaksanaan pekerjaan (baik dari segi teknis, waktu, dan kualitas pekerjaannya), mengelola jadwal proyek yang didasarkan pada metode kerja, berkomunikasi dengan pimpinan mengenai hal-hal yang berkaitan dengan pelaksanaan proyek, dan mengadakan kontrol disiplin kerja kepada tenaga kerja agar bekerja sesuai dengan tugas, kewajiban, dan wewenang masing-masing. Selain itu, terdapat juga manajer teknik yang memiliki tugas untuk mengarahkan dan memotivasi seluruh pekerja dalam timnya untuk mencapai target agar memenuhi persyaratan waktu, mutu, biaya, dan safety yang sudah disepakati, memantau pekerjaan teknis dan menganalisa apabila terjadi penyimpangan dalam pelaksanaan pekerjaan, membuat laporan kegiatan proyek serta menyiapkan detail materi laporan bulanan, dan membuat perencanaan dan mengatur kegiatan operasional engineering (Djojo dan Andi, 2016).

\section{Kinerja}

Zainullah et al. (2012) mengatakan bahwa kinerja merupakan hasil atau tingkat keberhasilan seseorang secara keseluruhan dalam melaksanakan tugasnya. Pada proyek konstruksi, tolak ukur kinerja dapat dilihat melalui (Alam, 2011 dalam Kerzner 2001):

1. Biaya (cost) : Biaya yang digunakan untuk mengerjakan suatu proyek tidak boleh melebihi anggaran yang tersedia.

2. Waktu (scheduling) : Pelaksanaan suatu proyek mempunyai rentang waktu yang telah ditargetkan dan harus dipenuhi. Apabila penyelesaian proyek semakin panjang (telat) maka kerugian yang ditimbulkan dapat semakin besar.

3. Mutu (quality) : Setiap kegiatan proyek harus menghasilkan suatu hasil akhir yang berkualitas, sesuai dengan perencanaan dan harus memenuhi spesifikasi teknis sesuai dengan yang disyaratkan oleh owner.

\section{Kinerja waktu}

Kinerja merupakan tingkat keberhasilan seseorang dalam melaksanakan tugasnya dan salah satu tugas manajer proyek konstruksi yaitu proyek yang dikerjakannya berjalan tepat waktu. Oleh karena itu, kinerja dari seorang manajer proyek konstruksi dapat dilihat dari kinerja waktu proyek yang sedang dikerjakannya. Penilaian terhadap kinerja waktu proyek didasarkan atas skala kinerja (skala 1 - 5) dengan penilaian sebagai berikut (Alam, 2011 dalam Sitorus, 2008):

$\begin{array}{lll}\text { 1. } & \text { Buruk } & \text { : Terlambat lebih dari }>16 \% \text { dari schedule } \\ \text { 2. } & \text { Sedikit Terlambat } & \text { : Terlambat antara }>8 \% \text { dan } \leq 16 \% \text { dari schedule } \\ \text { 3. } & \text { Rata }- \text { Rata } & \text { : Terlambat antara } \geq 0 \% \text { dan } \leq 8 \% \text { dari schedule } \\ \text { 4. } & \text { Agak Baik } & \text { : Lebih cepat antara }>0 \% \text { dan } \leq 4 \% \text { dari schedule } \\ \text { 5. } & \text { Baik } & \text { : Lebih cepat }>4 \% \text { dari } \text { schedule }\end{array}$




\section{METODOLOGI PENELITIAN}

\section{Populasi dan sampel penelitian}

Populasi dalam penelitian ini adalah para manajer proyek konstruksi yang berada di kawasan DKI Jakarta. Sampel pada penelitian ini diambil lebih dari 30 responden. Metode pengambilan sampel menggunakan metode non probability sampling. Teknik sampling yang digunakan adalah purposive sampling yaitu pengambilan sampel yang membatasi pada ciri-ciri khusus seseorang. Kriteria dalam pengambilan sampel penelitian adalah menjabat sebagai seorang manajer proyek konstruksi yang meliputi manajer proyek, site manager, manajer engineering, manajer komersial, dan manajer-manajer lainnya.

\section{Teknik pengumpulan data}

Pengumpulan data menggunakan kuesioner yang telah disusun dan pengukuran menggunakan skala Likert seperti pada tabel 1 .

Tabel 1. Skala Likert Penelitian

\begin{tabular}{cc}
\hline Skala & Penilaian \\
\hline 1 & Tidak Berpengaruh \\
\hline 2 & Kurang Berpengaruh \\
\hline 3 & Cukup Berpengaruh \\
\hline 4 & Berpengaruh \\
\hline 5 & Sangat Berpengaruh \\
\hline
\end{tabular}

\section{Diagram Alir Penelitian}

Studi ini ingin melakukan analisis pengaruh motivasi dan disiplin kerja terhadap kinerja manajer proyek konstruksi yang dapat dilihat seperti pada diagram alir pada Gambar 1.

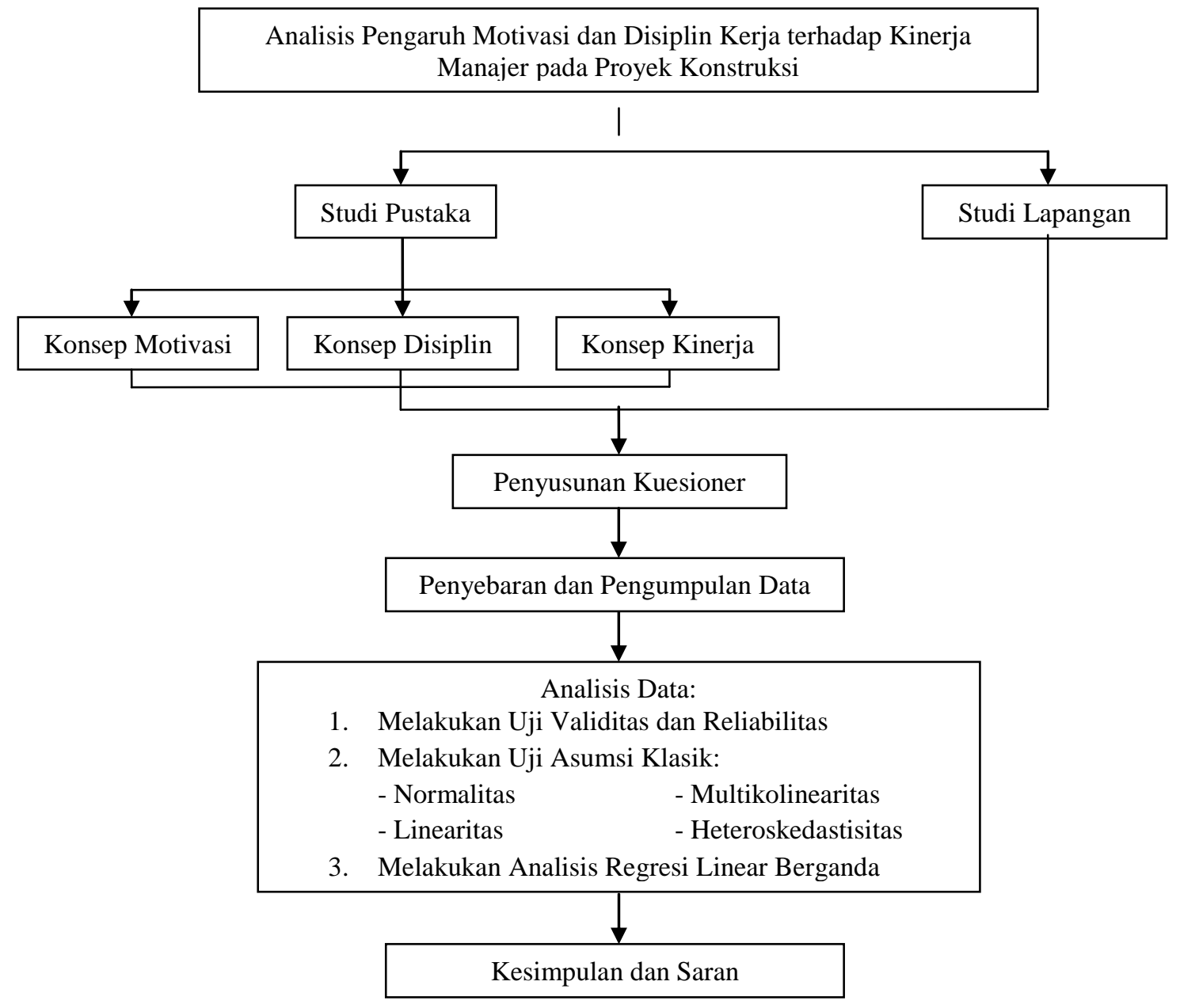

Gambar 1. Diagram Alir Penelitian 


\section{Variabel Penelitian}

Dari hasil tinjauan pustaka dari beberapa literatur yang dilakukan pada bab sebelumnya, maka didapatkan variabel yang digunakan dalam penelitian adalah sebagai berikut.

Tabel 2. Variabel-Variabel Motivasi dan Disiplin Kerja

\begin{tabular}{|c|c|}
\hline No. & Faktor-Faktor Motivasi dan Disiplin Kerja \\
\hline \multicolumn{2}{|r|}{ Kelompok A : Motivasi Kerja } \\
\hline \multicolumn{2}{|r|}{ A.1 Faktor Kebutuhan Fisiologis } \\
\hline A.1.1 & Gaji yang diberikan cukup untuk memenuhi kebutuhan \\
\hline A.1.2 & Adanya bonus dan upah tambahan \\
\hline A.1.3 & Adanya pembayaran upah lembur \\
\hline A.1.4 & Fasilitas pekerjaan pada proyek yang baik \\
\hline A.1.5 & Bayaran yang diterima tepat waktu \\
\hline A.1.6 & Kesesuaian gaji dengan pekerjaan yang dilakukan \\
\hline \multicolumn{2}{|r|}{ A.2 Faktor Kebutuhan Rasa Aman } \\
\hline A.2.1 & Program keselamatan kerja yang baik \\
\hline A.2.2 & Program kesehatan kerja yang baik \\
\hline \multicolumn{2}{|r|}{ A.3 Faktor Kebutuhan Sosial } \\
\hline A.3.1 & Program pengarahan dan pelatihan kerja yang baik \\
\hline A.3.2 & Kondisi lingkungan tempat kerja proyek yang baik \\
\hline A.3.3 & Adanya dukungan dari keluarga \\
\hline A.3.4 & Memiliki hubungan baik antar sesama rekan kerja dalam proyek dan dapat diajak bekerja sama \\
\hline A.3.5 & Memiliki rasa saling percaya dengan atasan \\
\hline \multicolumn{2}{|r|}{ A.4 Faktor Kebutuhan Pengakuan } \\
\hline A.4.1 & Memiliki pekerjaan yang menantang \\
\hline A.4.2 & Adanya pengakuan sebagai bagian dari organisasi proyek \\
\hline A.4.3 & Adanya pengakuan dan penghargaan dari atasan berdasarkan kinerja/hasil pekerjaan \\
\hline A.4.4 & Adanya kesempatan promosi/kenaikan jabatan bila melakukan prestasi dalam bekerja \\
\hline A.4.5 & Kenaikan gaji diberikan apabila dapat bekerja dengan baik \\
\hline \multicolumn{2}{|r|}{ A.5 Faktor Aktualisasi Diri } \\
\hline A.5.1 & Adanya partisipasi dalam pembuatan keputusan \\
\hline A.5.2 & Meraih keberhasilan terhadap pekerjaan yang dilakukan \\
\hline A.5.3 & Dapat memberi dampak positif atau manfaat terhadap orang lain \\
\hline A.5.4 & Memiliki kesempatan untuk berkembang dalam pekerjaan \\
\hline \multicolumn{2}{|r|}{ Kelompok B : Disiplin Kerja } \\
\hline B.1 & Selalu mematuhi dan menjalankan peraturan yang ditetapkan dalam proyek dengan sungguh-sungguh \\
\hline B.2 & Merasa tenang atau nyaman jika dapat menyelesaikan tugas dengan baik \\
\hline B.3 & Selalu berusaha untuk tetap masuk kerja jika tidak ada alasan yang sangat penting \\
\hline B.4 & Selalu hadir dalam bekerja \\
\hline B.5 & Terbiasa datang tepat waktu \\
\hline B.6 & Selalu memanfaatkan waktu sebaik mungkin \\
\hline B.7 & Tugas yang dikasih langsung dilakukan \\
\hline B.8 & Bekerja sesuai dengan jam kerja yang telah ditentukan oleh perusahaan \\
\hline B.9 & Selalu teliti dan cermat dalam menyelesaikan pekerjaan \\
\hline B.10 & Pekerjaan yang dilakukan mengikuti prosedur kerja yang ditetapkan dalam proyek \\
\hline B.11 & Selalu pulang setelah semua pekerjaan diselesaikan dengan baik \\
\hline B.12 & Merasa bertanggung jawab terhadap pekerjaan yang dilakukan \\
\hline
\end{tabular}

\section{Pengujian Data}

Pengujian dilakukan dengan menggunakan bantuan software SPSS. Adapun teknik analisis data yang dilakukan dalam penelitian ini meliputi uji validitas dan reliabilitas, uji asumsi klasik (terdiri atas uji normalitas, linearitas, multikolinearitas, heteroskedastisitas), uji koefisien determinasi, uji t, dan uji F. 


\section{ANALISIS DAN PEMBAHASAN}

\section{Distribusi dan pengumpulan data}

Kuesioner yang disebar kepada responden ada sebanyak 52 kuesioner dan jumlah kuesioner yang kembali adalah sebanyak 38 kuesioner. Dari kuesioner yang terkumpul, sebanyak 38 kuesioner dapat digunakan untuk analisis data.

\section{Uji validitas}

Uji validitas dilakukan dengan melihat nilai $r$ hitung pada kolom corrected total item correlation. Apabila nilai $r$ hitung $\geq \mathrm{r}$ tabel, maka butir tersebut dapat dikatakan valid. Butir yang tidak valid harus direduksi mulai dari yang memiliki nilai $\mathrm{r}$ terkecil. Dengan jumlah responden sebanyak 38 orang $(\mathrm{N}=38)$, maka dari tabel $\mathrm{r}$ dengan $\mathrm{df}=\mathrm{N}-2=$ 38-2 = 36 dan taraf signifikansi 5\% akan didapatkan nilai $r$ tabel sebesar 0,329. Hasil uji validitas menunjukkan bahwa variabel B.2, variabel A.4.3, dan variabel A.2.1 tidak valid sehingga harus direduksi.

\section{Uji reliabilitas}

Uji reliabilitas dilakukan dengan melihat nilai cronbach's alpha yang harus lebih besar dari 0,6. Dari hasil analisis Setelah melakukan reduksi terhadap 3 buah variabel agar memenuhi syarat validitas, nilai cronbach's alpha didapat seperti pada tabel 3 .

Tabel 3. Nilai Cronbach's Alpha

\begin{tabular}{|r|r|}
\hline Cronbach's Alpha & N of Items \\
\hline, 938 & 31 \\
\hline
\end{tabular}

Dari tabel di atas dapat disimpulkan bahwa data penelitian ini memiliki reliabilitas yang sangat tinggi.

\section{Analisis deskriptif}

Analisis deskriptif dilakukan untuk mendapatkan nilai rata-rata (mean) dari keseluruhan variabel yang ditanyakan kepada beberapa responden. Hal ini bertujuan untuk mengetahui variabel yang paling berpengaruh dan menentukan dari motivasi dan disiplin kerja.

Tabel 4. Hasil Analisis Deskriptif

\begin{tabular}{|c|c|c|c|}
\hline \multicolumn{4}{|c|}{ Descriptive Statistics } \\
\hline Variabel Motivasi Kerja & Mean & Variabel Disiplin Kerja & Mean \\
\hline A.1.1 & 4,1316 & B.1 & 4,0000 \\
\hline A.1.2 & 3,9211 & B.3 & 3,8158 \\
\hline A.1.3 & 3,6316 & B.4 & 3,9211 \\
\hline A.1.4 & 3,7632 & B.5 & 3,9737 \\
\hline A.1.5 & 3,9737 & B.6 & 3,9737 \\
\hline A.1.6 & 4,0526 & B.7 & 4,0263 \\
\hline A.2.2 & 4,0526 & B. 8 & 3,6842 \\
\hline A.3.1 & 4,0526 & B.9 & 4,0263 \\
\hline A.3.2 & 3,8421 & B.10 & 3,9474 \\
\hline A.3.3 & 4,0000 & B.11 & 3,7895 \\
\hline A.3.4 & 4,2632 & B.12 & 4,3158 \\
\hline A.3.5 & 3,9474 & Rata-Rata & 3,9522 \\
\hline A. 4.1 & 3,6579 & & \\
\hline A. 4.2 & 3,7105 & & \\
\hline A. 4.4 & 4,0000 & & \\
\hline A. 4.5 & 3,9211 & & \\
\hline A.5.1 & 3,6579 & & \\
\hline A.5.2 & 4,0000 & & \\
\hline A.5.3 & 3,9474 & & \\
\hline A.5.4 & 3,9737 & & \\
\hline Rata-Rata & 3,9250 & & \\
\hline
\end{tabular}


Dari tabel 3, dapat dilihat bahwa motivasi kerja memiliki nilai rata-rata (mean) sebesar 3,9250 sedangkan disiplin kerja memiliki nilai rata-rata sebesar 3,9522. Sehingga dapat disimpulkan disiplin kerja lebih berpengaruh terhadap kinerja manajer proyek konstruksi.

\section{Uji normalitas}

Uji normalitas dilakukan dengan melihat grafik Normal Probability Plot. Dari gambar 2 dapat dilihat bahwa data menyebar di sekitar garis diagonal dan mengikuti arah garis diagonal. Oleh karena itu, dapat ditarik kesimpulan bahwa data tersebut terdistribusi secara normal.

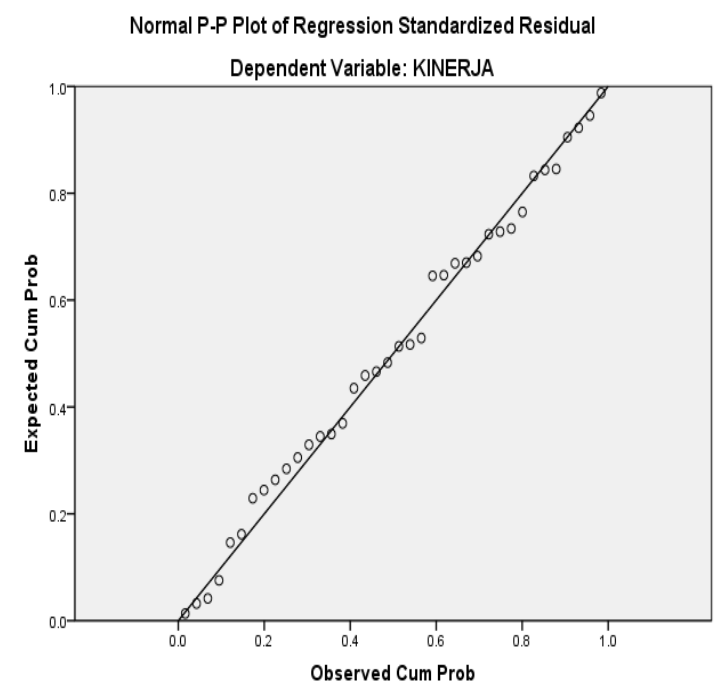

Gambar 2. Grafik Normal Probability Plot

\section{Uji linearitas}

Hasil pengujian pada tabel 5 menunjukkan kedua nilai Sig. pada motivasi maupun disiplin $<0,05$. Oleh karena itu, dapat disimpulkan variabel motivasi dan disiplin bersifat linear.

Tabel 5. Hasil Uji Linearitas

\begin{tabular}{|c|c|c|c|c|c|c|c|}
\hline & & & $\begin{array}{l}\text { Sum of } \\
\text { Squares }\end{array}$ & df & $\begin{array}{l}\text { Mean } \\
\text { Square }\end{array}$ & $\mathbf{F}$ & Sig. \\
\hline \multirow{5}{*}{$\begin{array}{l}\text { KINERJA * } \\
\text { MOTIVASI }\end{array}$} & \multirow{3}{*}{$\begin{array}{l}\text { Between } \\
\text { Groups }\end{array}$} & (Combined) & 21,702 & 23 & ,944 & 2,331 &, 052 \\
\hline & & Linearity & 13,289 & 1 & 13,289 & 32,832 &, 000 \\
\hline & & Deviation from Linearity & 8,413 & 22 &, 382 & ,945 &, 561 \\
\hline & \multicolumn{2}{|c|}{ Within Groups } & 5,667 & 14 & ,405 & & \\
\hline & \multicolumn{2}{|c|}{ Total } & 27,368 & 37 & & & \\
\hline \multirow{5}{*}{$\begin{array}{l}\text { KINERJA * } \\
\text { DISIPLIN }\end{array}$} & \multirow{3}{*}{$\begin{array}{l}\text { Between } \\
\text { Groups }\end{array}$} & (Combined) & 21,368 & 19 & 1,125 & 3,374 & ,006 \\
\hline & & Linearity & 13,853 & 1 & 13,853 & 41,559 &, 000 \\
\hline & & Deviation from Linearity & 7,515 & 18 &, 418 & 1,253 & ,319 \\
\hline & \multicolumn{2}{|c|}{ Within Groups } & 6,000 & 18 & ,333 & & \\
\hline & \multicolumn{2}{|l|}{ Total } & 27,368 & 37 & & & \\
\hline
\end{tabular}

\section{Uji multikolinearitas}

Dari tabel 6 dapat dilihat nilai tolerance lebih besar dari 0,1 dan nilai VIF lebih kecil dari 10, sehingga dapat disimpulkan bahwa tidak adanya multikolinearitas pada model regresi ini.

Tabel 6. Nilai Tolerance dan VIF

\begin{tabular}{|c|c|c|c|}
\hline & \multirow{2}{*}{ Model } & \multicolumn{2}{|c|}{ Collinearity Statistics } \\
\hline & & Tolerance & VIF \\
\hline \multirow[t]{3}{*}{1} & (Constant) & & \\
\hline & MOTIVASI &, 523 & 1,913 \\
\hline & DISIPLIN &, 523 & 1,913 \\
\hline
\end{tabular}




\section{Uji heteroskedastisitas}

Dari grafik pada Gambar 3 dapat dilihat bahwa titik-titik tersebut tidak membentuk pola seperti gelombang besar, melebar ataupun menyempit sehingga dapat ditarik kesimpulan bahwa model regresi ini tidak mengalami heterokedastisitas.

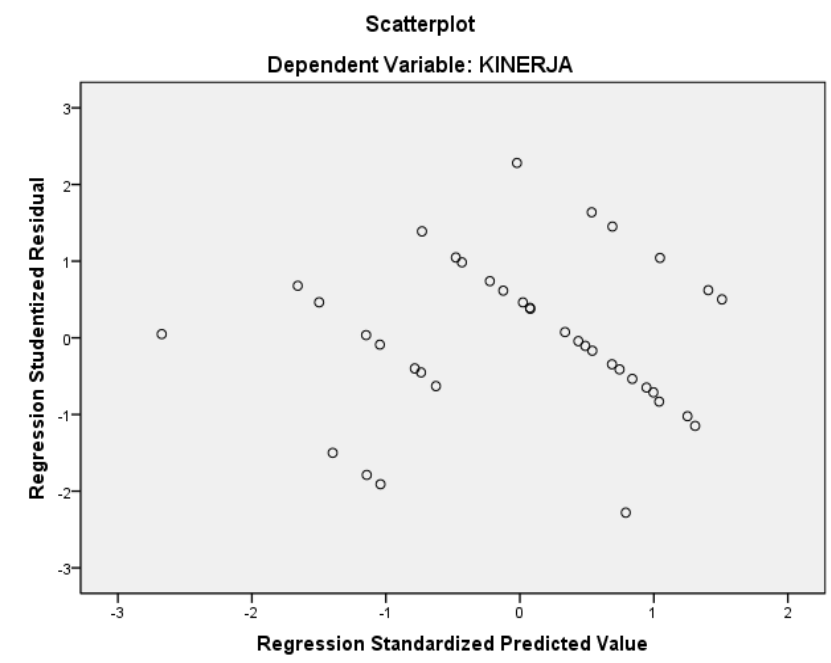

Gambar 3. Grafik Scatter Plot

\section{Analisis regresi linear berganda}

Setelah melakukan uji asumsi klasik dan telah memenuhi syarat, maka data dapat digunakan untuk analisis regresi. Analisis terdiri dari uji koefisien determinasi, uji t, dan uji F.

\section{Uji koefisien determinasi}

Dari tabel 7 dapat dilihat nilai adjusted $R$ square adalah sebesar 0,563. Hal ini menunjukkan bahwa motivasi dan disiplin kerja mampu memberikan pengaruh sebesar 56,3\% terhadap kinerja manajer proyek konstruksi. Sedangkan 43,7\% sisanya sipengaruhi oleh variabel-variabel bebas lainnya yang tidak diteliti dalam penelitian ini.

Tabel 7. Hasil Uji Koefisien Determinasi

\begin{tabular}{clrrr}
\hline Model & R & R Square & Adjusted R Square & \multicolumn{1}{c}{ Std. Error of the Estimate } \\
\hline 1 &, $766^{\mathrm{a}}$ & 0,587 & 0,563 & 0,56842
\end{tabular}

\section{Persamaan Regresi}

Dari hasil pengujian yang telah dilakukan, didapatkan tabel nilai koefien seperti di bawah (tabel 8).

Tabel 8 Tabel Nilai Koefisien

\begin{tabular}{|c|c|c|c|}
\hline \multirow{2}{*}{\multicolumn{2}{|c|}{ Model }} & \multicolumn{2}{|c|}{ Unstandardized Coefficients } \\
\hline & & $\mathbf{B}$ & Std. Error \\
\hline \multirow{3}{*}{1} & (Constant) & $-1,816$ & 0,793 \\
\hline & MOTIVASI & 0,033 & 0,013 \\
\hline & DISIPLIN & 0,068 & 0,023 \\
\hline
\end{tabular}

Dari tabel tersebut, maka terbentuk persamaan regresi sebagai berikut.

$$
Y=-1,816+0,033 A+0,068 B
$$

dengan:

$\mathrm{Y}=$ Variabel Kinerja Manajer Proyek Konstruksi 


\section{A $=$ Faktor Motivasi \\ $\mathrm{B}=$ Faktor Disiplin}

Intepretasi dari persamaan regresi pada halaman sebelumnya adalah sebagai berikut:

a. Jika terjadi peningkatan motivasi kerja (A) sebesar 1\%, maka akan terjadi peningkatan terhadap kinerja manajer proyek konstruksi (Y) sebesar $0,033 \%$.

b. Jika terjadi peningkatan disiplin kerja (B) sebesar 1\%, maka akan terjadi peningkatan terhadap kinerja manajer proyek konstruksi (Y) sebesar 0,068\%.

c. Apabila motivasi (A) dan disiplin kerja (B) memiliki nilai 0, maka nilai kinerja manajer proyek konstruksi adalah $-1,816$.

\section{Uji signifikansi individual (Uji t)}

Tabel 9. Hasil Uji Signifikansi Individual (Uji T)

\begin{tabular}{llll}
\hline & Model & $\mathrm{t}$ & Sig. \\
\hline 1 & $($ Constant $)$ & $-2,290$ &, 028 \\
& MOTIVASI & 2,613 &, 013 \\
& DISIPLIN & 2,928 &, 006
\end{tabular}

Dari uji tersebut (Tabel 9), maka hipotesis dapat dijawab sebagai berikut:

a. Hipotesis Pertama

$\mathrm{H}_{0}$ : Tidak ada pengaruh motivasi kerja terhadap kinerja secara signifikan

$\mathrm{H}_{1}$ : Ada pengaruh motivasi kerja terhadap kinerja secara signifikan

Dari tabel $\mathrm{t}$ dengan $\mathrm{df}=\mathrm{n}-\mathrm{k}=38-3=35$ dan taraf signifikansi 5\%, didapat nilai $\mathrm{t}$ tabel $=2,0301$. Motivasi kerja memiliki $\mathrm{t}$ hitung sebesar 2,613 > t tabel $(\mathrm{Sig} .<0,05)$. Hal ini membuktikan bahwa $\mathrm{H}_{0}$ ditolak sehingga disimpulkan bahwa motivasi kerja mempunyai pengaruh yang signifikan terhadap kinerja dari seorang manajer proyek konstruksi.

b. Hipotesis Kedua

$\mathrm{H}_{0}$ : Tidak ada pengaruh disiplin kerja terhadap kinerja secara signifikan

$\mathrm{H}_{1}$ : Ada pengaruh disiplin kerja terhadap kinerja secara signifikan

Disiplin kerja memiliki $t$ hitung sebesar 2,938 > t tabel (Sig. <0,05), hal ini membuktikan bahwa $\mathrm{H}_{0}$ ditolak sehingga disimpulkan bahwa disiplin kerja mempunyai pengaruh yang signifikan terhadap kinerja dari seorang manajer proyek konstruksi.

Dari kedua variabel tersebut, disiplin kerja memiliki nilai t hitung lebih besar dibandingkan dengan motivasi kerja, maka dapat diketahui bahwa disiplin kerja lebih dibandingkan dengan motivasi kerja.

\section{Uji signifikansi simultan (Uji F)}

Tabel 10. Hasil Uji Signifikansi Simultan (Uji F)

\begin{tabular}{|c|c|c|c|c|c|c|}
\hline & Model & Sum of Squares & df & Mean Square & $\mathrm{F}$ & Sig. \\
\hline \multirow[t]{3}{*}{1} & Regression & 16,060 & 2 & 8,030 & 24,853 &, $000^{\mathrm{a}}$ \\
\hline & Residual & 11,309 & 35 & ,323 & & \\
\hline & Total & 27,368 & 37 & & & \\
\hline
\end{tabular}

Dari uji tersebut, maka hipotesis dapat dijawab sebagai berikut: 
$\mathrm{H}_{0} \quad$ : Tidak ada pengaruh antara variabel bebas (motivasi dan disiplin kerja) secara bersamaan terhadap variabel terikatnya (kinerja) secara signifikan.

$\mathrm{H}_{1} \quad$ : Ada pengaruh antara variabel bebas (motivasi dan disiplin kerja) secara bersamaan terhadap variabel terikatnya (kinerja) secara signifikan.

Dari tabel $\mathrm{F}$ dengan $\mathrm{df}_{1}=\mathrm{k}-1=3-1=2$ dan $\mathrm{df}_{2}=\mathrm{n}-\mathrm{k}=38-3=35$ (taraf signifikansi 5\%), didapat nilai $\mathrm{F}$ tabel $=$ 3,267. F hitung didapat sebesar 24,853 > F tabel (Sig.<0,05), hal ini membuktikan bahwa $\mathrm{H}_{0}$ ditolak sehingga dapat disimpulkan bahwa motivasi dan disiplin kerja secara bersama-sama mempunyai pengaruh yang signifikan terhadap kinerja dari seorang manajer proyek konstruksi.

\section{KESIMPULAN}

Berdasarkan hasil analisis yang dilakukan, maka dapat ditarik kesimpulan sebagai berikut:

1. Dari kelompok motivasi kerja, faktor yang paling memengaruhi kinerja manajer proyek konstruksi adalah memiliki hubungan baik antar sesama rekan kerja dalam proyek dan dapat diajak bekerja sama. Faktor berikutnya yang paling berpengaruh adalah gaji yang diberikan cukup untuk memenuhi kebutuhan.

2. Dari kelompok disiplin kerja, faktor yang paling memengaruhi kinerja manajer proyek konstruksi adalah merasa bertanggung jawab terhadap pekerjaan yang dilakukan. Faktor berikutnya yang paling berpengaruh adalah tugas yang dikasih langsung dilakukan dan selalu teliti dan cermat dalam menyelesaikan pekerjaan.

3. Motivasi dan disiplin kerja mampu memberikan pengaruh sebesar 56,3\% terhadap kinerja manajer proyek konstruksi.

4. Antara kelompok motivasi dan disiplin kerja, kelompok disiplin kerja lebih memengaruhi kinerja manajer proyek konstruksi dibandingkan dengan motivasi kerja.

\section{DAFTAR PUSTAKA}

Alam, Toni. (2011). Identifikasi Faktor-Faktor Risiko Proyek Rancang Bangun (Design and Build) pada PT. XYZ yang Berpengaruh Terhadap Kinerja Waktu. Universitas Indonesia.

Almutahar, Fajar F., Nurul W., dan Rafie. (2015). "Pengaruh Usia, Pengalaman Kerja, Disiplin Kerja dan Motivasi Kerja Terhadap Produktivitas Pekerja pada Pekerjaan Pemasangan Dinding Batako”. Jurnal Mahasiswa Teknik Sipil Universitas Tanjungpura, Vol. 1:1-11.

Aziz, H. dan Benny H. (2017). "Motivasi Pekerja pada Proyek Konstruksi di Padang”. Jurnal Rekayasa Sipil (JRSUNAND, Vol. 13:29-42.

Bangun, Wilson. (2012). Manajemen Sumber Daya Manusia. Jakarta: Erlangga.

Djojo, Mariza S. dan Andi. (2016). Proyek Gold Coast Office Tower Jakarta. Jakarta: Universitas Tarumanagara.

Musmawarny, Endang dan Anton Soekiman. (2015). "Pengaruh Motivasi Terhadap Kinerja Tukang pada Beberapa Proyek Konstruksi di Kota Bandung”. Jurnal Seminar Nasional Teknik Sipil V, 57-70.

Nadiah, Jan Agustina, dan Liana Herlina. (2012). "Faktor Disiplin Meningkatkan Produktivitas Tenaga Kerja Pada Proyek Konstruksi”. Jurnal Sipil, Vol. 12:150-161.

Narpaduhita, Daniswara. (2016). Pengaruh Disiplin Kerja dan Motivasi Kerja Terhadap Kinerja Mandor (Studi pada Proyek Pembangunan Hotel di Yogyakarta). Universitas Atma Jaya Yogyakarta.

Sekarsari, Jane. (2018). Sistem Informasi Manajemen (Teori dan Konsep Aplikasi pada Sektor Konstruksi). Jakarta: Universitas Trisakti.

Wang, D., D. Arditi dan A. Damci. (2017). “Construction Project Managers Motivators and Human Values. Journal of Construction Engineering and Management”. Journal Construction Engineering and Management, Vol. 143.

Widayaningtyas, Rika. (2016). Pengaruh Disiplin Kerja dan Motivasi Kerja terhadap Kinerja Karyawan. Universitas Negeri Yogyakarta.

Yusuf. Tugas-Tugas Manajer dan Tanggung Jawab Manajer Terlengkap. http://jurnalmanajemen.com/tugasmanajer/. 